\title{
AN OVERWIEV ON PUBLIC-PRIVATE-PARTNERSHIP PROJECTS: A CASE OF TURKEY
}

\section{DOI: 10.17261/Pressacademia.2019.1148 PAP-IFC- V.10-2019(16)-p.80-84}

\section{Suat Teker ${ }^{1}$, Dilek Teker ${ }^{2}$}

${ }^{1}$ Isik University, Maslak Campus, Istanbul, Turkey. suat.teker@isikun.edu.tr, ORCID: 0000-0002-7981-3121

${ }^{2}$ Isik University, Maslak Campus, Istanbul, Turkey. dilek.teker@isikun.edu.tr, ORCID: 0000-0002-3893-4015

\section{To cite this document}

Teker, S., Teker, D., (2019). An overwiev on public-private-partnership projects: a case of Turkey. PressAcademia Procedia (PAP), V.10, p.80-84.

Permemant link to this document: http://doi.org/10.17261/Pressacademia.2019.1148

Copyright: Published by PressAcademia and limited licenced re-use rights only.

\begin{abstract}
Purpose- The aim of this paper is to review the PPP projects that have undertaken in Turkey over a period of 1980-2018.

Methodology- The statistics of PPP projects are examined in terms of the number of projects, values of investments, sectoral distribution. Findings- Turkey is one of the top users of PPP financing models to construct public projects by comparing the some other countries initiating lots of PPP projects over a long period.

Conclusion- In order to achieve success in this complex structure consisting of public, sponsors and financiers in PPP, it is critical to prepare a good project. Predictability of the project obligations will minimize the possibility of additional costs in the future. Ensuring that the tendering and contracting processes are correctly configured, hence, all project risks can be identified and the risk sharing can be done more accurately.
\end{abstract}

Keywords: Public private partnership (PPP), Turkey, efficiency, infrastructure, public projects.

JEL Codes: G40, G41

\section{INTRODUCTION}

A public-private partnership (PPP) is an arrangement between a public authority and a private partner designed to deliver a public infrastructure project and service under a long-term contract. Under this contract, the private partner bears significant risks and management responsibilities. The public authority makes performance-based payments to the private partner for the provision of the service (e.g. for the availability of a road) or grants the private partner a right to generate revenues from the provision of the service (e.g. tolls from users of a bridge). Private finance is usually involved in a PPP project. When properly prepared, PPP projects can provide significant benefits to the public sector as well as to the project.

Properties of a public-private-partnership project can be summarized as a long-term contract between a public authority and a private partner focusing on the provision of services rather than assets (long term), the transfer of certain project risks to the private partner, notably with regard to designing, building, operating/maintaining and/or financing the Project (risk transfer), a focus on the specification of project outputs rather than project inputs, taking account of the whole life cycle implications for the Project (focus on output), the application of private financing (often "project finance") to underpin the risks transferred to the private partner (private financing), the public authority makes performance-based payments to the private partner for the provision of the service (e.g. for the availability of a road) or grants the private partner a right to generate revenues from the provision of the service (e.g. tolls from users of a bridge). (payments by public authority)

The question of why a PPP option instead of convetional public procurement preferred may be answered by the rationale for using a PPP instead of conventional public procurement rests on the proposition that optimal risk sharing with the private partner delivers better "value for money" for the public sector and ultimately the end users. PPPs can be more complex than conventional public procurement. They require detailed project preparation and planning and proper management of the procurement phase to incentive competition among bidders. They also require careful contract design to set service standards, allocate risks and reach an acceptable balance between commercial risks and returns. These features require skills in the public sector which are not typically called for in conventional procurement.

Six core principles of good governance in PPP projects may be listed as below;

- Efficiency - use of resources without waste, delay, corruption, or undue burden on future generations

- Accountability - the extent to which political actors are responsible to society for their actions

- Transparency - clarity and openness in decision-making 
- Decency - development and implementation of rules without harming people

- Fairness - equal application of rules to all members of society

- Participation - involvement of all stakeholders

By utilization of PPP models on public projects some gains are expected to be obtained. PPP models are expected to lower cost of operations over the life of the project. produce more effective distribution of risks. increase in speed of completing the projects, increase in quality in public services. creating new sources for public revenues, and convey a more effective public administration.

This research paper covers the advantages of puclic-private-partnership project financing model over traditonal public procurement. The following section briefly covers an overview of PPP projects employed in Turkey in between years 1986-2018 and examines some other countries' PPP projects. Finaly, some considerations and suggestions are put forward to improve the way of implication of PPP financing

\section{PPP MODELS APPLIED IN TURKEY}

The most commonly used PPP models in Turkish public projects are BOT, BO, BRT and TOOR. BOT model has used to build, motorways, airports, bridges, tunnels, national parks and covers $45 \%$ of whole PPP projects in Turkey. BO model has used to run coal power plants that covers $8 \%$, BRT model has used to build and run cith hospitals that covers $45 \%$ and TOOR model has used to build custom facilities, marinas, turizm facilities and extract mines that covers $2 \%$ of whole projects in Turkey.

By employing various PPP mpdels in years 1980 and 2018, a total number of 242 public projects have been contructed with an investment value of 64.8 billion USD, a value of transfered rights of 76.2 bilion USD. Table 1 below shows the number of PPP projects, sectors and investmen values in between 1986-2018.

\section{Table 1: PPP Project of Turkey (1986-2018)}

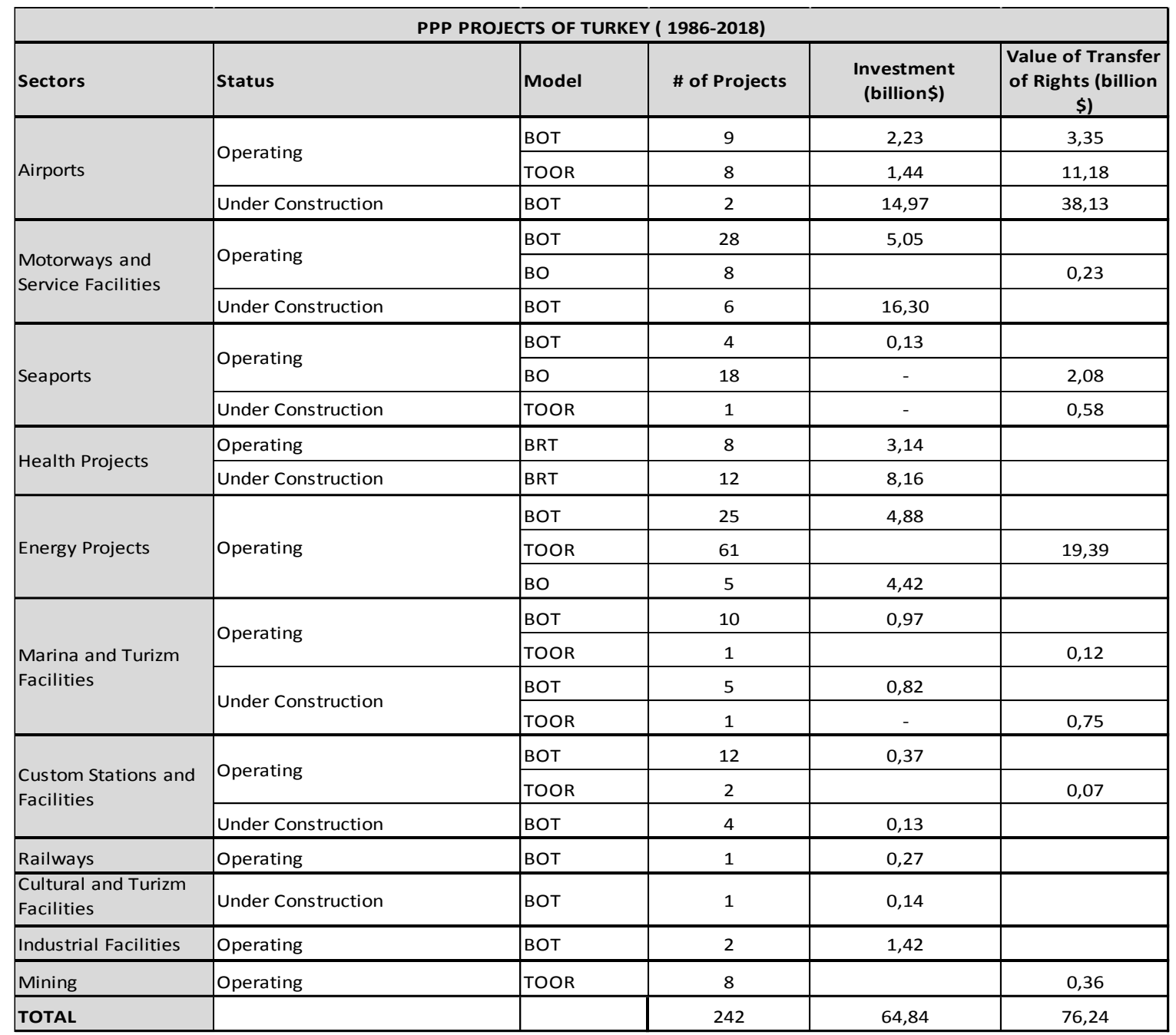


Table 2 presents the sectoral distribution and investment value of PPP projects in Turkey. The largest sector in PPP projects is the energy covering $36.6 \%$ of all with an investment value of 28.71 billion USD. The second and thrid largets sectors of PPP, respectively, are airports and motorways covering $7.9 \%$ and $17.4 \%$ of number of PPP projects with an investment values of 71.3 and 21.2 billion USD.

Table 2: Sectoral Distribution of PPP Projects in Turkey

\begin{tabular}{|l|c|c|}
\hline Sectors & $\%$ & Billion \$ \\
\hline Energy & 36,6 & 28,71 \\
\hline Airports & 7,9 & 71,3 \\
\hline Motorways & 17,4 & 21,2 \\
\hline Health & 9,3 & 11,3 \\
\hline Seaports & 9,8 & 2,79 \\
\hline Industrial Facilities & 0,9 & 1,43 \\
\hline Marinas and Facilities & 7,6 & 1,79 \\
\hline Railways & 0,4 & 0,27 \\
\hline Custom Stations & 6,7 & 0,51 \\
\hline Cultural and Turizm Facilities & 0,4 & 0,14 \\
\hline Mining & 3,3 & 0,37 \\
\hline Total & $\mathbf{1 0 0}$ & $\mathbf{1 3 9 , 8 1}$ \\
\hline
\end{tabular}

Table 3 below presents the numbers and values of PPP projects in Brasil, Argentina, South Afrika and England. In the period of 1990 and 2018, 911 PPP projects with a total investment value of 388 billion USD have undertaken in Brasil. 226 projects with an investment value of 56 billion USD has constracted in Argentina while 100 PPP projects with an investment value of 23 billion USD has contracted in South Africa in the same period. In the period of 1993 and 2017, England has undertaken 214 PPP projects with an investmen value of 161 billion USD.

Table 3: PPP Projects Undertaken in the Other Countries

\begin{tabular}{|l|c|c|c|c|c|c|}
\hline $\mathbf{1 9 9 0}$ - 2018 & \multicolumn{2}{|c|}{ Brasil } & \multicolumn{2}{c|}{ Argentina } & \multicolumn{2}{c|}{ South Africa } \\
\hline Sectors & \# of Projects & Billion \$ & \# of Projects & Billion \$ & \# of Projects & Billion \$ \\
\hline Seaports & 64 & 12,5 & 16 & 0,9 & & \\
\hline Telecommunicaton & 35 & 34,5 & 3 & 1,2 & 4 & 0,8 \\
\hline Airports & 22 & 28,6 & 5 & 2,4 & 4 & 0,2 \\
\hline Motorways & 73 & 49,7 & 45 & 5,5 & 9 & 1,8 \\
\hline Railways & 20 & 35,7 & 18 & 5,6 & 1 & 3,5 \\
\hline Water-Sanitation & 153 & 16,3 & 19 & 8,2 & 8 & 0,09 \\
\hline Natural Gas & 21 & 10,5 & 10 & 9 & 2 & 1,2 \\
\hline Electric & 523 & 200,6 & 110 & 23,5 & 72 & 16 \\
\hline TOTAL & 911 & $\mathbf{3 8 8 , 4}$ & $\mathbf{2 2 6}$ & $\mathbf{5 6 , 3}$ & $\mathbf{1 0 0}$ & $\mathbf{2 3 , 5 9}$ \\
\hline
\end{tabular}

\begin{tabular}{|l|c|c|}
\hline $1993-\mathbf{2 0 1 7}$ & \multicolumn{2}{|c|}{ England } \\
\hline Sectors & \# of Projects & Billion \$ \\
\hline Health & 64 & 12,5 \\
\hline Education & 35 & 34,5 \\
\hline Sanitation & 22 & 28,6 \\
\hline Housing & 73 & 49,7 \\
\hline Military Facilities & 20 & 35,7 \\
\hline TOTAL & 214 & 161 \\
\hline
\end{tabular}

Table 4 shows the biggest projects to be contracted in the World in 2018. The first three biggest projects among the world's largets projects list belong to Turkey. The Dardanelles Bridge costs 3.1 billion Euro, the Ankara-Nigde Motorway costs 1.2 billion Euro and the Gironde Network cost 1,2 billion Euro.

Table 4: The Biggest PPP Projects (2018)

\begin{tabular}{|c|l|l|c|}
\hline Rank & Country & Project Name & Billion€ \\
\hline 1 & Turkey & Dardanelles Bridge & 3,1 \\
\hline 2 & Turkey & Ankara-Nigde Motorway & 1,2 \\
\hline 3 & France & Gironde Network & 1,2 \\
\hline 4 & Holland & Blankenburg Tunnel & 1 \\
\hline 5 & Holland & A16 Rotterdam Motorway & 0,93 \\
\hline 6 & Holland & Afsluitdjik Dam & 0,81 \\
\hline 7 & Turkey & Bilkent Labs & 0,71 \\
\hline 8 & Germany & A10/A24 Neuruppin-Pankow Motorway & 0,65 \\
\hline & & TOTAL & 9,6 \\
\hline
\end{tabular}




\section{CONCLUSION}

Urbanization, population increase, climate changes, technological developments, macroeconomic targets of governmests have been changing. Additions and renovations are needed in infrastructures. World Banks estimates that a 94 billion USD is needed for infrastructure investments up to year 2040. PPP projects have oftenly applied for transportation, health and energy sector. PPP model is expected to apply for less scaled projects and other sectors in the future. The existing PPP regulations should be consalidated and revised to meet the needs of new PPP models and sectors. The decision must be made based upon economic, social, financial physibility and return of expenditures. Viable PPP projects must be subject to sectoral and projects vise prioritization in order to use resources for the macraeconomic and strategic targets.

Moreover, a large number of PPP projects competes in international markets. In order to reach financing, the projects presented to investors should cover all detailes, well documented and provide good returns for the country. The whole procedures of PPP projects must be transparent for all parties. Effective monitoring, evaluation and performance management ensure improved PPP management. The preparation of PPP guidelines to be transferred to new PPP projects from previous projects ensures the standardization and predictability of PPP processes, while ensuring the institutional capacity of the public. Alternative financing methods appropriate to PPP should be evaluated and technical and legal infrastructure should be prepared. In order to achieve success in this complex structure consisting of public, sponsors and financiers in PPP, it is critical to prepare a good project. Predictability of the project obligations will minimize the possibility of additional costs in the future. Ensuring that the tendering and contracting processes are correctly configured, hence, all project risks can be identified and the risk sharing can be done more accurately.

\section{REFERENCES}

Ahmad, U., Ibrahim, Y., Minai, M.S., (2017). Public Private Partnership in Malaysia: The Differences in Perceptions on the Criticality of Risk Factors and Allocation of Risks between the Private and Public Sectors. International Review of Management and Marketing, 7(2), $138-150$.

Akimova, Y. A., Kochetkova, S.A., Kovalenko, E.G., Zinina, L.I.,(2016). Public-Private Partnership in Agribusiness. International Review of Management and Marketing, 6(4), 814-822.

Bayazıt, B., Alper, G., (2017). Ultrahazardous Activity Liability In PPP Models: Efficient Allocation of Risk. Ankara Üniversitesi Hukuk Fakültesi Dergisi, 66 (1), 1-47.

Benedict, O., (2013). The Performance of Nigeria Economy and the State of Infrastructural Development and Management. Journal of International Environmental Application \& Science, Vol. 8 (2): 304-307.

Boz, S.S., (2013). Kamu Özel İşbirliği (PPP) Modeli . İnönü Üniversitesi Hukuk Fakültesi Dergisi Cilt: 4 Sayı:2 277-332.

Bulbul, D., (2017). Evaluation of the Public Private Partnership Practices in Terms of Financial Transparency in Turkey. The Journal of International Scientific Researches, V.2(7), 94-108.

Canbaz, M., (2019). Küresel Dinamiklerin Kamu Özel İşbirliğine Yaklaşımı: Türkiye İçin Finansal Bir Değerlendirme. İktisadi Yenilik Dergisi, Cilt: 6, Sayı: 2, 46-75.

Çiçek, H., Alicavuşoğlu, Ç., (2016). Türkiye'de Ulaştırma Sektöründe Kamu-Özel Sektör İşbirlikleri: Tokat İli Örneği. Gaziosmanpasa University Social Sciences Researches Journal . V.11(1), 77-93.

Cumhurbaşkanlığı Strateji ve Butçe Başkanlğı, (2019). Kamu-Ozel Isbirliği Raporu. Https://www.Sbb.Gov.Tr/WpContent/Uploads/2019/05/Kamu-Ozel Isbirligi Raporu-2018.Pdf

Emek, U., (2017). Sağlık Sektöründe Kamu-Özel İşbirliği Sözleşmeleri: Beklenti Ve Gerçekleşme. Hacettepe HFD, 7(1) 2017, 139-168

European Expertise Centrew $\underline{\text { Https://www.Eib.Org/Epec/ }}$

Gedik, M.A., (2012). Mali Özgürlük: Avrupa Bölgesi İçin Bir Değerlendirme. Afyon Kocatepe Üniversitesi, IiBF Dergisi ( C.XIV, S.I, $231-250$.

Glazyrina, I.,Lavlinskii, S., (2017). Transaction Costs and Prospects for Public-Private Partnership in the Russian Mineral Resourse Sector. International Journal of Economics and Financial Issues, 7(1), 403-413.

İnanc, H., Dönmez, C.Ç., (2018). Evaluation of Value Capture Strategies for Public Private Partnership Projects in Railway System Projects to be Built in Istanbul City. Marmara Fen Bilimleri Dergisi, 3, 286-298

Kahyaoğulları, B., (2013). Public-Private Partnerships in Developing and Developed Countries: the UK and Turkish Cases. Afyon Kocatepe Üniversitesi, iiBF Dergisi, C. XV, S. II, 243-276

Kalkınma Bakanlığı, Kamu-Özel İşbirliği Mevzuatı (2015). Http://Www.Sbb.Gov.Tr/Wp-Content/Uploads/2018/10/Kamu-\%C3\%96zel\%C4\%B0\%C5\%9Fbirli\%C4\%9Fi-Mevzuat\%C4\%B1-2015.Pdf

Kaptan, A.K., Teker, S., (2019). Public Private Partnership Projects: Eurasia Tunnel, PAP- V.9-2019(47)-P.253-256

Khoteeva, M., Khoteeva, D. (2017). Public-Private Partnerships: A Solution for Infrastructure Development in the UK? Case Study of the London Underground Public-Private Partnership Project. International Review of Management and Marketing, 2017, 7(1), 300-308.

Kurukcu, M., Coskun, H., (2019). The Evaluation of Public Private Partnership Models in Terms of Turkish Fiscal Policy. Journal of Life Economics Cilt, Volume 6, Sayı/Issue 3, 2019, P. 361-378 
Matraeva, L.V., Konov, A.A., Belyak, A.V., Erokhin, S.G., Vasyutina, E.S., (2016). Public Private Partnership in Social Sphere: Models Review. International Journal of Economics and Financial Issues, 6(S8) 127-136.

Lukmanova, G. I., Mishlanova, M.Y.,(2015). Economics and Society in the Era of Technological Changes and Globalization Determinant Analysis of Public-Private Partnership in Russia. International Journal of Economics and Financial Issues, Special Issue, $208-216$.

Nel, D., (2018). An Assessment of Emerging Hybrid Public-Private Partnerships in the Energy Sector in South Africa Internatıonal Journal of Economics and Finance Studies Vol 10(1), 34-49.

Oktem, B., (2016). Atık Yönetiminde Entegre Uygulama. Journal of Life Sciences; V.6 (2/1), 135-147.

Pombo, O.A., Santes-Álvarez, R.V., (2012). An Alternative to the Governance of Water Services in Mexico: The Model of the New Water Culture. Social Sciences Research Journal, V.1(1), 1-15.

Teker, D.L., (2005). Sağık Sektöründe Proje Finansman Modelleri: Türkiye İçin Bir Model Önerisi ve Bir Hastane Projesinin Fizibilite Analizi. Hastane Yönetimi Dergisi, 1-18

Tekin, P.Ş., (2017). Küresel Kamu Özel Ortaklığı Uygulamaları ve Türkiye Sağlık Sektörü Açısından Bir Değerlendirme Ankara Sağlık Hizmetleri Dergisi, Cilt 16, Sayı 2, 5-20.

Tekin, P.Ş., Çelik, Y. (2012). Analysing Public -Private Partnership Policy as a Financing Method in Turkey Health Sector with Political Mapping. Ankara Sağlık Bilimleri Dergisi, 1(3), 81-98

Uğur, A., Miynat, M., (2014). Kamu Özel Sektör Ortaklıklarının Ekonomi Politiği. Yönetim ve Ekonomi. Cilt:21 Sayı:2, $19-40$.

Usta, S., Bilgiç, E., (2016). Yerel Yönetimlerde Hizmet Sunumu: Kamu Özel Ortaklığı Model. Journal of Süleyman Demirel University Institute of Social Sciences, V.1(23), 249-267.

Uz, A., (2007). Kamu-Özel Ortaklı̆̆ı/Public-Private Partnership (PPP) Kavram ve Hukuksal Çerçeve. Gazi Universitesi Hukuk Fakultesi Dergisi C. XI, S.1-2, 1165-1182

Uysal, Y., (2017). Yerel Yönetimlerde Kamu Özel İşbirliği (KÖi) Uygulamalarının İki Yönü: Avantajlar ve Dezavantajlar. Journal of Urban Academy, Volume: 10 Issue: 2, 164-169.

Uysal, Y., (2018). Comparative Analysis of Public Private Partnership (PPP) Investments in Selected Countries of European Union and Turkey. International Journal of Management Academy.V.1,(2),158-173 